\title{
Criteria pollutant dispersion modeling analysis for the Harir Early Production Facility, Kurdistan Region of Iraq
}

\author{
D. G. A. Ganjo \\ Department of Biology, Salahaddin University, Iraq
}

\begin{abstract}
Anticipated air emissions including $\mathrm{NO}_{\mathrm{x}}, \mathrm{SO}_{2}, \mathrm{H}_{2} \mathrm{~S}$ and $\mathrm{CO}$ resulting from flaring of gas for the Harir Early Production Facility, Northern Iraq (where this work was carried out) were followed up for impact assessment on existing ambient air quality via dispersion modeling. Due to the absence of upper layer meteorological data, stability class and mixing height for the ground layer for Iraq, prediction of the Ground Level Concentration (GLC) of emissions were made using the software of Industrial Sources Complex Short Term Model version 3 (ISCST3). ISCST3 software was used by default internationally for available ground layer mixing height and stability class. GLCs were calculated using meteorological data collected from the meteorological station at site during the monitoring period i.e. from 24 Sep. 2010 to 23 Oct. 2010. Air emissions were analyzed directly at the field using a portable gas analyzer Drager-Multiwarn, Germany. Topography of the studied area $10 \mathrm{~km}^{2}$ around the project site (considered for impact assessment) is undulating in nature with contours varying from $700 \mathrm{~m}$ to $1550 \mathrm{~m}$. Two assumptions were made while using the model; no dry and wet depletion of pollutants and the EPF location of $1550 \mathrm{~m}$. Maximum 24 hourly averages incremental GLCs of emissions during flaring were predicted for the grid size of $250 \mathrm{~m}^{2}$ and 81 grids. The first maximum 50 values of 24 hourly incremental GLCs of emissions were then calculated. Contours for maximum 24 hourly averages incremental GLCs of air emissions were drawn at specified concentrations given for each and corresponding isopleth were depicted. It was evident from the modeling that maximum values of 24 hourly GLCs for $\mathrm{H}_{2} \mathrm{~S}$ and $\mathrm{SO}_{2}$ severely surpassed Environmental, Health and Safety Guidelines for Onshore Oil and Gas Development of International Finance Corporation (IFC). Suitable mitigations and recommendations were made.

Keywords: $\mathrm{NO}_{x}, \mathrm{SO}_{2}, \mathrm{H}_{2} \mathrm{~S}, \mathrm{CO}, \mathrm{EPF}, \mathrm{ISCST3}$.
\end{abstract}




\section{Introduction}

Atmospheric dispersion modeling is the mathematical simulation of how air pollutants disperse in the ambient atmosphere (Al-Hamad and Khan [1] and Villasenor et al. [2]). Air quality assessment by integrating measurement techniques and modeling tools is a crucial element in pollution mitigation (Dahl and Kuralbaya [3]). However, in many countries systematic measurements for the monitoring and evaluation of air quality are not available, mainly due to lack of resources and regulations [4]. Procedures for preparing an emission summary and dispersion modeling report and analysis have been discussed by Turner [5] and Berkowicz et al. [6]. The most commonly used dispersion model is Industrial Source Complex - Short Term, or ISCST3. This program allows for the modeling of many stacks, building data, receptor locations and hourly meteorological data are required to run an ISCST3 model (United States Environmental Protection Agency, EPA [7]).

Iraq (including Kurdistan, the Northern Region of Iraq) is a major oil producing country and its economy directly depends on its export of crude and refined products. The processed oil is exported or refined at large refining industries. Separated gas that cannot be utilized economically is flared. This flaring produces a number of undesirable atmospheric emissions, including $\mathrm{CO}$, $\mathrm{CO}_{2}, \mathrm{SO}_{2}, \mathrm{H}_{2} \mathrm{~S}, \mathrm{NOx}$. More recently, so many production facilities are established in the region. These activities result in the emission of gaseous pollutants to the atmosphere, particularly from the flaring of undesirable product and excess gases. Iraq does not have upper layer meteorological data. Even stability class and mixing height for ground layer are not available in Iraq for lower layer meteorological data. The objective of this work was to obtain an accurate estimation of the total flare emission from the Harir EPF activities, using ISCST3 software by default internationally available ground layer mixing height and stability class, thereby aiding the effective planning of mitigation strategies to control and reduce the pollution from crude related operation.

\section{The project}

Harir Early Production Facility/System (EPF) is located at $36.5709 \mathrm{~N}$ by 44.3734E and 1462m.a.s.1, Northern Iraq (fig. 1). The EPF consists of the following equipment and emission sources:

- A separator with vent routed to flare;

- Process heated with vent routed to flare;

- Amine system with vent routed to flare;

- $\quad$ Possible crude $\mathrm{H}_{2} \mathrm{~S}$ stripper tower with vent routed to flare;

- Flare device;

- $\quad$ Two 30,000 barrel oil storage tanks vented to atmosphere;

- $\quad$ Truck loading facility; 


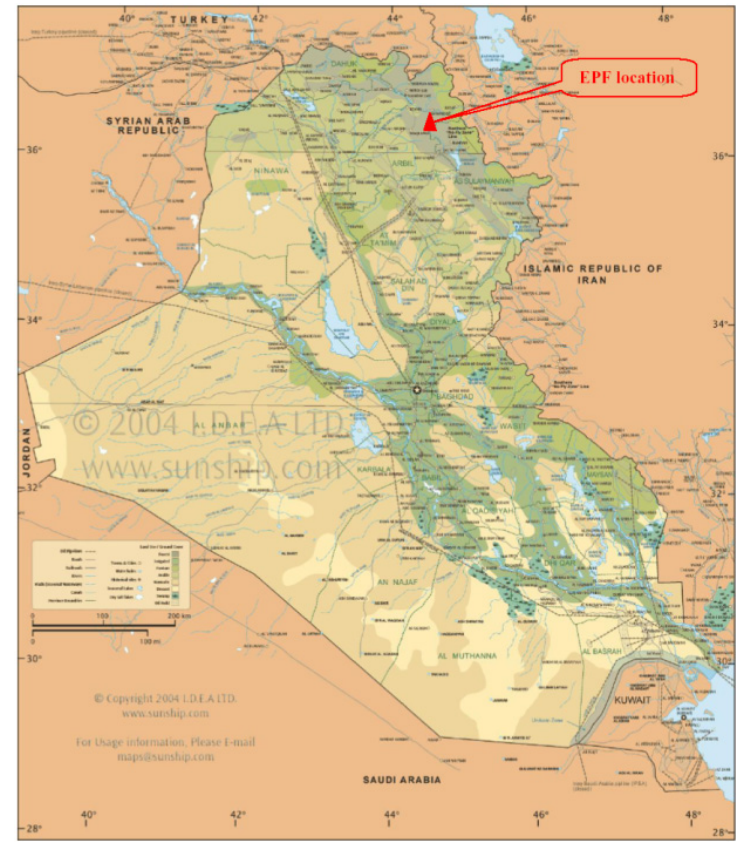

Figure 1: $\quad$ Map of Iraq, location of the EPF is indicated.

\section{Methodology}

Inputs, including gaseous pollutants $\mathrm{NO}_{\mathrm{x}}, \mathrm{SO}_{2}, \mathrm{H}_{2} \mathrm{~S}$ and $\mathrm{CO}$ resulting from flaring of gas for the Harir Early Production Facility were analyzed directly in the field using a portable gas analyzer Drager-Multiwarn, Germany. The instrument was calibrated against high purity standard gases, following the instrument instruction manual given by Drager Laboratories. The 24 hour average concentrations of gaseous pollutants were estimated at each location. Weather conditions were normal and there was no excess wind during the measurements. The measured values were logged into the instrument memory, and subsequently downloaded.

GLCs were calculated by using hourly meteorological data collected from the meteorological station at site during the monitoring period i.e. from 24 September 2010 to 23 October 2010.

Topography of the study area $(10 \mathrm{~km} \times 10 \mathrm{~km}$ around the project site) considered for impact assessment is undulating in nature with contours varying from $700 \mathrm{~m}$ to $1550 \mathrm{~m}$ above m.a.s.l. The following are the assumptions made while using the model:

- No dry and wet depletion of pollutants; and

- Proposed location of EPF is at $1550 \mathrm{~m}$ above m.a.s.l. 
The emission characteristics and other details of flaring considered for the modeling are summarized in table 1.

Table 1: Details of emission from flaring of gas.

\begin{tabular}{cc}
\hline Particulars & Details \\
\hline Quantity of gas to be flared & $15000 \mathrm{mcf} / \mathrm{d}$ \\
\hline Number of Stack & 1 \\
\hline Stack height $(\mathrm{m})$ & $150 \mathrm{ft}(45.72 \mathrm{~m})$ \\
\hline Stack diameter & $8^{\prime \prime}(0.203 \mathrm{~m})$ \\
\hline Gas Temperature $\left({ }^{\circ} \mathrm{C}\right)$ & $125^{\circ} \mathrm{F}\left(324.7^{\circ} \mathrm{K}\right)$ \\
\hline Gas velocity $(\mathrm{m} / \mathrm{s})$ & $335 \mathrm{ft} / \mathrm{s}(102.1 \mathrm{~m} / \mathrm{s})$ \\
\hline Emission rate & \\
\hline $\mathrm{NO}_{\mathrm{x}}$ & $11.03 \mathrm{~g} / \mathrm{s}(2100 \mathrm{lb} / \mathrm{day} @ 140 \mathrm{lb} / \mathrm{MMscf}$ of gas $)$ \\
\hline $\mathrm{SO}_{2}$ & $930.76 \mathrm{~g} / \mathrm{s}(7387 \mathrm{lb} / \mathrm{hr})$ \\
\hline $\mathrm{H}_{2} \mathrm{~S}$ & $495.05 \mathrm{~g} / \mathrm{s}(3929 \mathrm{lb} / \mathrm{hr})$ \\
\hline $\mathrm{CO}$ & $1.57 \mathrm{~g} / \mathrm{s}(300 \mathrm{lb} / \mathrm{day} @ 20 \mathrm{lb} / \mathrm{MMscf}$ of gas $)$ \\
\hline
\end{tabular}

\section{Results and discussion}

Output of the modeling is described hereunder:

\subsection{Oxides of nitrogen $\left(\mathrm{NO}_{\mathrm{x}}\right)$}

Maximum 24 hourly average incremental GLCs of $\mathrm{NO}_{\mathrm{x}}$ during flaring are predicted for the grid size of $250 \mathrm{~m} \times 250 \mathrm{~m}$ and 81 grids. The first maximum 50 values of 24 hourly incremental GLCs of $\mathrm{NO}_{\mathrm{x}}$ are given in table 2. Contours for maximum 24 hourly average incremental GLCs of $\mathrm{NO}_{\mathrm{x}}$ are drawn at an interval of $10.0 \mu \mathrm{g} / \mathrm{m}^{3}$ with minimum contour of $5.0 \mu \mathrm{g} / \mathrm{m}^{3}$ and corresponding isopleth is depicted in fig. 1. It is evident from the above discussion that the maximum 24 hourly average incremental GLC value for $\mathrm{NO}_{\mathrm{x}}$ due to flaring is predicted as $52.2 \mu \mathrm{g} / \mathrm{m}^{3}$ at a distance of $707 \mathrm{~m}$ in southwest (SW) direction with an average value of $2.05 \mu \mathrm{g} / \mathrm{m}^{3}$ within an area of $10 \mathrm{~km}$ radius around the facility. Contours of the GLCs depict that the travel of emissions would be mainly in S-W quadrant.

\subsection{Sulphur dioxide $\left(\mathrm{SO}_{2}\right)$}

Maximum 24 hourly average incremental GLCs of $\mathrm{SO}_{2}$ during flaring are predicted for the grid size of $250 \mathrm{~m} \times 250 \mathrm{~m}$ and 81 grids. The first maximum 50 values of 24 hourly incremental GLCs of $\mathrm{SO}_{2}$ are given in table 3. Contours for 
Table 2: 24 hourly average incremental GLCs of $\mathrm{NO}_{\mathrm{x}}\left(\mu \mathrm{g} / \mathrm{m}^{3}\right)$.

\begin{tabular}{|c|c|c|c|c|c|c|c|}
\hline \multirow{2}{*}{ S.n. } & \multirow{2}{*}{ Conc. } & \multicolumn{2}{|c|}{ Receptor (m) } & \multirow{2}{*}{ S.n. } & \multirow{2}{*}{ Conc. } & \multicolumn{2}{|c|}{ Receptor (m) } \\
\hline & & $(\mathrm{X})$ & $(\mathrm{Y})$ & & & $(\mathrm{X})$ & $(\mathrm{Y})$ \\
\hline 1 & 52.2 & -500 & -500 & 26 & 43.1 & -1250 & -3000 \\
\hline 2 & 51.1 & -500 & -500 & 27 & 42.9 & -4500 & -4500 \\
\hline 3 & 49.1 & -500 & -500 & 28 & 42.9 & -3000 & -3000 \\
\hline 4 & 48.0 & -250 & -750 & 29 & 42.8 & -500 & -500 \\
\hline 5 & 47.1 & -4000 & -4000 & 30 & 42.5 & -4750 & -4750 \\
\hline 6 & 47.0 & -4250 & -4250 & 31 & 42.5 & -6250 & -6250 \\
\hline 7 & 47.0 & -3750 & -3750 & 32 & 42.3 & -750 & -750 \\
\hline 8 & 46.8 & -4500 & -4500 & 33 & 42.2 & -2500 & -2500 \\
\hline 9 & 46.7 & -3500 & -3500 & 34 & 42.2 & -2750 & -2750 \\
\hline 10 & 46.5 & -4750 & -4750 & 35 & 42.2 & -500 & -500 \\
\hline 11 & 46.1 & -3250 & -3250 & 36 & 42.0 & -5000 & -5000 \\
\hline 12 & 46.1 & -250 & -500 & 37 & 41.8 & -500 & -250 \\
\hline 13 & 46.0 & -5000 & -5000 & 38 & 41.7 & -6500 & -6500 \\
\hline 14 & 45.3 & -5250 & -5250 & 39 & 41.6 & -750 & -250 \\
\hline 15 & 45.2 & -3000 & -3000 & 40 & 41.3 & -5250 & -5250 \\
\hline 16 & 44.6 & -5500 & -5500 & 41 & 41.2 & -2500 & -2500 \\
\hline 17 & 44.5 & -750 & -750 & 42 & 41.0 & -6750 & -6750 \\
\hline 18 & 44.0 & -2750 & -2750 & 43 & 41.0 & -1000 & -2500 \\
\hline 19 & 43.9 & -5750 & -5750 & 44 & 40.9 & -1500 & -3500 \\
\hline 20 & 43.6 & -3750 & -3750 & 45 & 40.6 & -5500 & -5500 \\
\hline 21 & 43.6 & -3500 & -3500 & 46 & 40.3 & -7000 & -7000 \\
\hline 22 & 43.5 & -4000 & -4000 & 47 & 40.2 & -1500 & -3750 \\
\hline 23 & 43.3 & -3250 & -3250 & 48 & 40.1 & -2500 & -6000 \\
\hline 24 & 43.3 & -4250 & -4250 & 49 & 40.0 & -2250 & -2250 \\
\hline 25 & 43.2 & -6000 & -6000 & 50 & 40.0 & -2250 & -2250 \\
\hline
\end{tabular}

Note: All receptors are grid card type and distances are in meters. 
maximum 24 hourly average incremental GLCs of $\mathrm{SO}_{2}$ are drawn at an interval of $500.0 \mu \mathrm{g} / \mathrm{m}^{3}$ with minimum contour of $100.0 \mu \mathrm{g} / \mathrm{m} 3$ and corresponding isopleth is depicted in fig. 2. It is evident from the above discussion that the maximum 24 hourly average incremental GLC value for $\mathrm{SO}_{2}$ due to flaring is predicted as $4402.2 \mu \mathrm{g} / \mathrm{m}^{3}$ at a distance of $707 \mathrm{~m}$ in southwest (SW) direction with an average value of $173.3 \mu \mathrm{g} / \mathrm{m}^{3}$ within an area of $10 \mathrm{~km}$ radius around the facility. Contours of the GLCs depict that the travel of emissions would be mainly in the S-W quadrant.

Table 3: 24 hourly average incremental GLCs of $\mathrm{SO}_{2}\left(\mu \mathrm{g} / \mathrm{m}^{3}\right)$.

\begin{tabular}{|c|c|c|c|c|c|c|c|}
\hline \multirow{2}{*}{ S.n. } & \multirow{2}{*}{ Conc. } & \multicolumn{2}{|c|}{ Receptor (m) } & \multirow{2}{*}{ S.n. } & \multirow{2}{*}{ Conc. } & \multicolumn{2}{|c|}{ Receptor (m) } \\
\hline & & $(\mathrm{X})$ & $(\mathrm{Y})$ & & & $(\mathrm{X})$ & $(\mathrm{Y})$ \\
\hline 1 & 4402.2 & -500 & -500 & 26 & 3639.7 & -1250 & -3000 \\
\hline 2 & 4308.6 & -500 & -500 & 27 & 3622.4 & -4500 & -4500 \\
\hline 3 & 4141.6 & -500 & -500 & 28 & 3619.6 & -3000 & -3000 \\
\hline 4 & 4050.5 & -250 & -750 & 29 & 3608.9 & -500 & -500 \\
\hline 5 & 3976.6 & -4000 & -4000 & 30 & 3586.8 & -4750 & -4750 \\
\hline 6 & 3969.5 & -4250 & -4250 & 31 & 3584.4 & -6250 & -6250 \\
\hline 7 & 3968.6 & -3750 & -3750 & 32 & 3569.8 & -750 & -750 \\
\hline 8 & 3950.2 & -4500 & -4500 & 33 & 3564.7 & -2500 & -2500 \\
\hline 9 & 3942.1 & -3500 & -3500 & 34 & 3561.0 & -2750 & -2750 \\
\hline 10 & 3921.1 & -4750 & -4750 & 35 & 3559.2 & -500 & -500 \\
\hline 11 & 3893.1 & -3250 & -3250 & 36 & 3543.5 & -5000 & -5000 \\
\hline 12 & 3890.5 & -250 & -500 & 37 & 3528.5 & -500 & -250 \\
\hline 13 & 3881.6 & -5000 & -5000 & 38 & 3522.9 & -6500 & -6500 \\
\hline 14 & 3825.4 & -5250 & -5250 & 39 & 3512.6 & -750 & -250 \\
\hline 15 & 3817.2 & -3000 & -3000 & 40 & 3486.6 & -5250 & -5250 \\
\hline 16 & 3766.9 & -5500 & -5500 & 41 & 3480.1 & -2500 & -2500 \\
\hline 17 & 3754.4 & -750 & -750 & 42 & 3461.7 & -6750 & -6750 \\
\hline
\end{tabular}


Table 3: $\quad$ (Continued).

\begin{tabular}{cccccccc}
\hline 18 & 3709.3 & -2750 & -2750 & 43 & 3457.9 & -1000 & -2500 \\
\hline 19 & 3706.8 & -5750 & -5750 & 44 & 3455.3 & -1500 & -3500 \\
\hline 20 & 3680.4 & -3750 & -3750 & 45 & 3428.6 & -5500 & -5500 \\
\hline 21 & 3676.6 & -3500 & -3500 & 46 & 3401.0 & -7000 & -7000 \\
\hline 22 & 3671.1 & -4000 & -4000 & 47 & 3396.0 & -1500 & -3750 \\
\hline 23 & 3657.3 & -3250 & -3250 & 48 & 3387.6 & -2500 & -6000 \\
\hline 24 & 3651.0 & -4250 & -4250 & 49 & 3379.4 & -2250 & -2250 \\
\hline 25 & 3645.8 & -6000 & -6000 & 50 & 3377.1 & -2250 & -2250 \\
\hline
\end{tabular}

Note: All receptors are grid card type and distances are in meters.

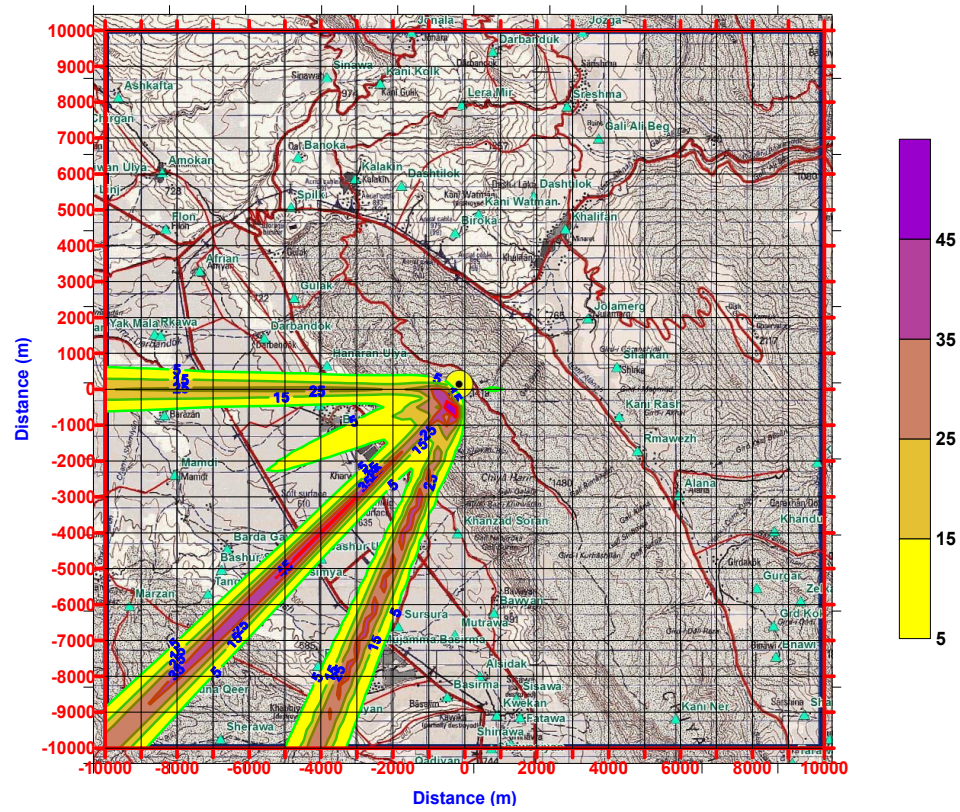

Figure 2: $\quad$ Contributed 24 hourly GLCs of $\mathrm{NO}_{\mathrm{x}}\left(\mu \mathrm{g} / \mathrm{m}^{3}\right)$.

\subsection{Hydrogen sulphide $\left(\mathrm{H}_{2} \mathrm{~S}\right)$}

Maximum 24 hourly average incremental GLCs of $\mathrm{H}_{2} \mathrm{~S}$ during flaring are predicted for the grid size of $250 \mathrm{~m} \times 250 \mathrm{~m}$ and 81 grids. The first maximum 50 values of 24 hourly incremental GLCs of $\mathrm{H}_{2} \mathrm{~S}$ are given in table 4. Contours for 
Table 4: 24 Hourly average incremental GLCs of $\mathrm{H}_{2} \mathrm{~S}\left(\mu \mathrm{g} / \mathrm{m}^{3}\right)$.

\begin{tabular}{|c|c|c|c|c|c|c|c|}
\hline \multirow{2}{*}{ S.n. } & \multirow{2}{*}{ Conc. } & \multicolumn{2}{|c|}{ Receptor (m) } & \multirow{2}{*}{ S.n. } & \multirow{2}{*}{ Conc. } & \multicolumn{2}{|c|}{ Receptor (m) } \\
\hline & & $(\mathrm{X})$ & $(\mathrm{Y})$ & & & $(\mathrm{X})$ & $(\mathrm{Y})$ \\
\hline 1 & 2341.2 & -500 & -500 & 26 & 1935.7 & -1250 & -3000 \\
\hline 2 & 2291.5 & -500 & -500 & 27 & 1926.5 & -4500 & -4500 \\
\hline 3 & 2202.6 & -500 & -500 & 28 & 1925.0 & -3000 & -3000 \\
\hline 4 & 2154.2 & -250 & -750 & 29 & 1919.3 & -500 & -500 \\
\hline 5 & 2114.9 & -4000 & -4000 & 30 & 1907.6 & -4750 & -4750 \\
\hline 6 & 2111.1 & -4250 & -4250 & 31 & 1906.3 & -6250 & -6250 \\
\hline 7 & 2110.6 & -3750 & -3750 & 32 & 1898.5 & -750 & -750 \\
\hline 8 & 2100.8 & -4500 & -4500 & 33 & 1895.8 & -2500 & -2500 \\
\hline 9 & 2096.5 & -3500 & -3500 & 34 & 1893.9 & -2750 & -2750 \\
\hline 10 & 2085.4 & -4750 & -4750 & 35 & 1892.9 & -500 & -500 \\
\hline 11 & 2070.5 & -3250 & -3250 & 36 & 1884.5 & -5000 & -5000 \\
\hline 12 & 2069.1 & -250 & -500 & 37 & 1876.6 & -500 & -250 \\
\hline 13 & 2064.4 & -5000 & -5000 & 38 & 1873.6 & -6500 & -6500 \\
\hline 14 & 2034.5 & -5250 & -5250 & 39 & 1868.1 & -750 & -250 \\
\hline 15 & 2030.1 & -3000 & -3000 & 40 & 1854.3 & -5250 & -5250 \\
\hline 16 & 2003.4 & -5500 & -5500 & 41 & 1850.8 & -2500 & -2500 \\
\hline 17 & 1996.7 & -750 & -750 & 42 & 1841.1 & -6750 & -6750 \\
\hline 18 & 1972.7 & -2750 & -2750 & 43 & 1839.0 & -1000 & -2500 \\
\hline 19 & 1971.4 & -5750 & -5750 & 44 & 1837.7 & -1500 & -3500 \\
\hline 20 & 1957.4 & -3750 & -3750 & 45 & 1823.5 & -5500 & -5500 \\
\hline 21 & 1955.4 & -3500 & -3500 & 46 & 1808.8 & -7000 & -7000 \\
\hline 22 & 1952.4 & -4000 & -4000 & 47 & 1806.1 & -1500 & -3750 \\
\hline 23 & 1945.1 & -3250 & -3250 & 48 & 1801.7 & -2500 & -6000 \\
\hline 24 & 1941.7 & -4250 & -4250 & 49 & 1797.3 & -2250 & -2250 \\
\hline 25 & 1939.0 & -6000 & -6000 & 50 & 1796.1 & -2250 & -2250 \\
\hline
\end{tabular}

Note: All receptors are grid card type and distances are in meters. 
maximum 24 hourly average incremental GLCs of $\mathrm{H}_{2} \mathrm{~S}$ are drawn at an interval of $200.0 \mu \mathrm{g} / \mathrm{m}^{3}$ with a minimum contour of $100.0 \mu \mathrm{g} / \mathrm{m}^{3}$ and corresponding isopleth is depicted in fig. 3. It is evident from the above discussion that the maximum 24 hourly average incremental GLC value for $\mathrm{H}_{2} \mathrm{~S}$ due to flaring is predicted as $2341.2 \mu \mathrm{g} / \mathrm{m}^{3}$ at a distance of $707 \mathrm{~m}$ in southwest (SW) direction with an average value of $92.2 \mu \mathrm{g} / \mathrm{m}^{3}$ within an area of $10 \mathrm{~km}$ radius around the facility. Contours of the GLCs depict that the travel of emissions would be mainly in the S-W quadrant.

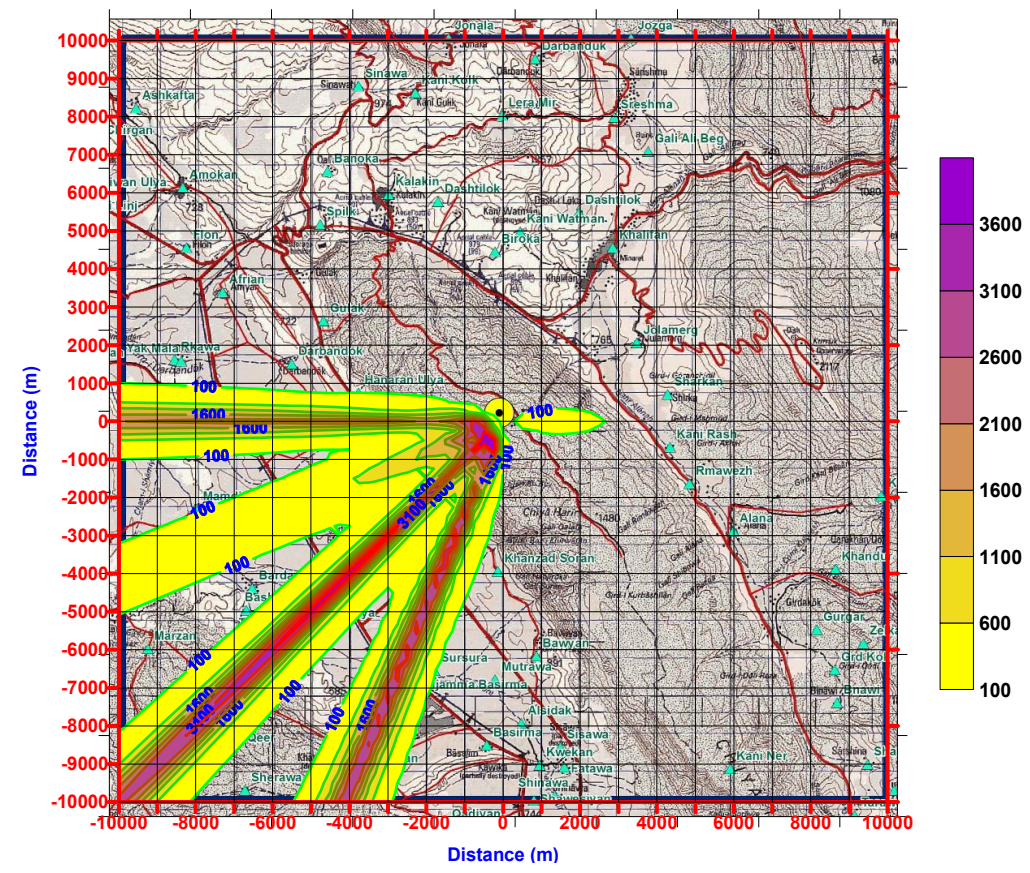

Figure 3: $\quad$ Contributed 24 hourly GLCs of $\mathrm{SO}_{2}\left(\mu \mathrm{g} / \mathrm{m}^{3}\right)$.

\subsection{Carbon monoxide (CO)}

Maximum 24 hourly average incremental GLCs of CO during flaring are predicted for the grid size of $250 \mathrm{~m} \times 250 \mathrm{~m}$ and 81 grids. The first maximum 50 values of 24 hourly incremental GLCs of $\mathrm{CO}$ are given in table 5. Contours for maximum 24 hourly average incremental GLCs of $\mathrm{CO}$ are drawn at an interval of $2.0 \mu \mathrm{g} / \mathrm{m}^{3}$ with minimum contour of $1.0 \mu \mathrm{g} / \mathrm{m}^{3}$ and corresponding isopleth is depicted in fig. 4. It is evident from the above discussion that maximum 24 hourly average incremental GLC value for $\mathrm{CO}$ due to flaring is predicted as $7.38 \mu \mathrm{g} / \mathrm{m}^{3}$ at a distance of $707 \mathrm{~m}$ in southwest (SW) direction with an average value of $0.3 \mu \mathrm{g} / \mathrm{m}^{3}$ within an area of $10 \mathrm{~km}$ radius around the facility. Contours of the GLCs depict that the travel of emissions would be mainly in S$\mathrm{W}$ quadrant. 
Table 5: 24 hourly average incremental GLCs of CO $\left(\mu \mathrm{g} / \mathrm{m}^{3}\right)$.

\begin{tabular}{|c|c|c|c|c|c|c|c|}
\hline \multirow{2}{*}{ S.n. } & \multirow{2}{*}{ Conc. } & \multicolumn{2}{|c|}{ Receptor (m) } & \multirow{2}{*}{ S.n. } & \multirow{2}{*}{ Conc. } & \multicolumn{2}{|c|}{ Receptor (m) } \\
\hline & & $(\mathrm{X})$ & $(\mathrm{Y})$ & & & $(\mathrm{X})$ & (Y) \\
\hline 1 & 7.38 & -500 & -500 & 26 & 6.10 & -1250 & -3000 \\
\hline 2 & 7.22 & -500 & -500 & 27 & 6.07 & -4500 & -4500 \\
\hline 3 & 6.94 & -500 & -500 & 28 & 6.07 & -3000 & -3000 \\
\hline 4 & 6.79 & -250 & -750 & 29 & 6.05 & -500 & -500 \\
\hline 5 & 6.66 & -4000 & -4000 & 30 & 6.01 & -4750 & -4750 \\
\hline 6 & 6.65 & -4250 & -4250 & 31 & 6.01 & -6250 & -6250 \\
\hline 7 & 6.65 & -3750 & -3750 & 32 & 5.98 & -750 & -750 \\
\hline 8 & 6.62 & -4500 & -4500 & 33 & 5.97 & -2500 & -2500 \\
\hline 9 & 6.61 & -3500 & -3500 & 34 & 5.97 & -2750 & -2750 \\
\hline 10 & 6.57 & -4750 & -4750 & 35 & 5.97 & -500 & -500 \\
\hline 11 & 6.53 & -3250 & -3250 & 36 & 5.94 & -5000 & -5000 \\
\hline 12 & 6.52 & -250 & -500 & 37 & 5.91 & -500 & -250 \\
\hline 13 & 6.51 & -5000 & -5000 & 38 & 5.90 & -6500 & -6500 \\
\hline 14 & 6.41 & -5250 & -5250 & 39 & 5.89 & -750 & -250 \\
\hline 15 & 6.40 & -3000 & -3000 & 40 & 5.84 & -5250 & -5250 \\
\hline 16 & 6.31 & -5500 & -5500 & 41 & 5.83 & -2500 & -2500 \\
\hline 17 & 6.29 & -750 & -750 & 42 & 5.80 & -6750 & -6750 \\
\hline 18 & 6.22 & -2750 & -2750 & 43 & 5.80 & -1000 & -2500 \\
\hline 19 & 6.21 & -5750 & -5750 & 44 & 5.79 & -1500 & -3500 \\
\hline 20 & 6.17 & -3750 & -3750 & 45 & 5.75 & -5500 & -5500 \\
\hline 21 & 6.16 & -3500 & -3500 & 46 & 5.70 & -7000 & -7000 \\
\hline 22 & 6.15 & -4000 & -4000 & 47 & 5.69 & -1500 & -3750 \\
\hline 23 & 6.13 & -3250 & -3250 & 48 & 5.68 & -2500 & -6000 \\
\hline 24 & 6.12 & -4250 & -4250 & 49 & 5.66 & -2250 & -2250 \\
\hline 25 & 6.11 & -6000 & -6000 & 50 & 5.66 & -2250 & -2250 \\
\hline
\end{tabular}

Note: All receptors are grid card type and distances are in meters. 


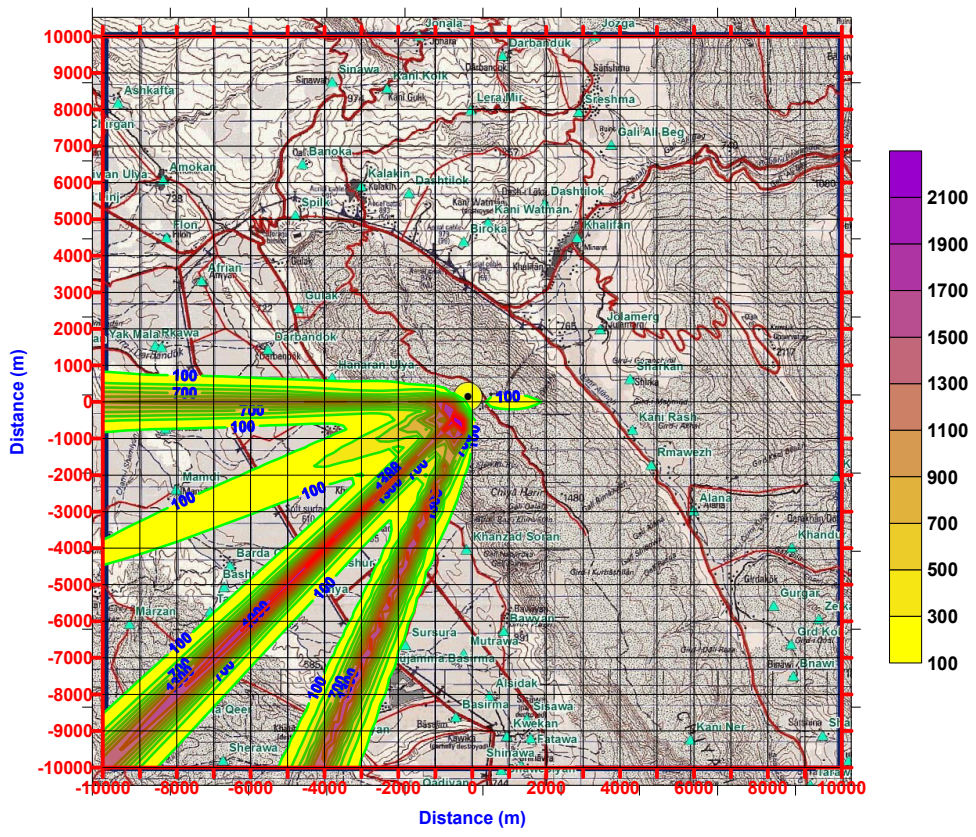

Figure 4: $\quad$ Contributed 24 hourly GLCs of $\mathrm{H}_{2} \mathrm{~S}\left(\mu \mathrm{g} / \mathrm{m}^{3}\right)$.

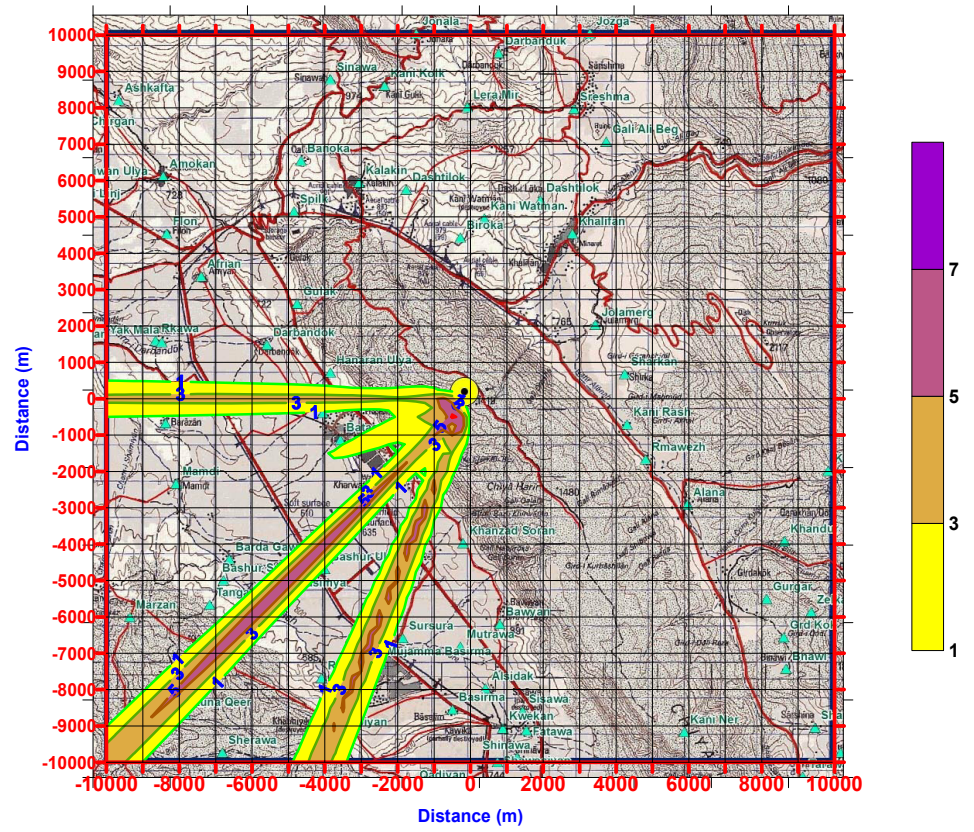

Figure 5: $\quad$ Contributed 24 hourly GLCs of CO $\left(\mu \mathrm{g} / \mathrm{m}^{3}\right)$. 


\section{Conclusion}

The details of GLCs for various pollutants based on modeling are summarized in table 6 below:

Table 6: Details of GLCs for various pollutants based on modelling.

\begin{tabular}{ccc}
\hline \multirow{2}{*}{ Pollutants } & \multicolumn{2}{c}{$\begin{array}{c}\text { Contributed GLCs }\left(\mu \mathrm{g} / \mathrm{m}^{3}\right) \text { within study area } \\
\text { (of } 10 \mathrm{~km} \text { radius around the EPF site) }\end{array}$} \\
\cline { 2 - 3 } & Maximum & Average \\
\hline $\mathrm{NO}_{\mathrm{x}}$ & 52.2 & 2.05 \\
\hline $\mathrm{SO}_{2}$ & 4402.2 & 173.3 \\
\hline $\mathrm{H}_{2} \mathrm{~S}$ & 2341.2 & 92.2 \\
\hline $\mathrm{CO}$ & 7.38 & 0.3 \\
\hline
\end{tabular}

It is evident from the modeling that the maximum values of 24 hourly GLCs for $\mathrm{H}_{2} \mathrm{~S}$ and $\mathrm{SO}_{2}$ are very high. It is due to considering higher emission values of $\mathrm{H}_{2} \mathrm{~S}$ during flaring for modeling. As per Environmental, Health and Safety Guidelines for Onshore Oil and Gas Development of International Finance Corporation (IFC), standard for $\mathrm{H}_{2} \mathrm{~S}$ emission during flaring should not be more than $5 \mathrm{mg} / \mathrm{Nm}^{3}$. SO $\mathrm{SO}_{2}$ generation shall be due to burning of $\mathrm{H}_{2} \mathrm{~S}$. Hence, value of emission of $\mathrm{SO}_{2}$ during flaring considered for modeling is also high however no standard has been prescribed by IFC.

\section{Recommendation}

Prediction of impacts are based on one month meteorological data only which are supposed to vary whole year. Hence, it is recommended that:

- Continuous online meteorological data should be monitored at the project site; and dispersion modeling should be carried out on monthly basis for the whole year.

- Development of a contingency plan for $\mathrm{H}_{2} \mathrm{~S}$ release events, including all necessary aspects from evacuation to resumption of normal operations. Installation of monitors set to activate warning signals whenever detected concentrations of $\mathrm{H}_{2} \mathrm{~S}$ exceed 7 milligrams per cubic meter $\left(\mathrm{mg} / \mathrm{m}^{3}\right)$. The number and location of monitors should be determined based on an assessment of plant locations prone to $\mathrm{H}_{2} \mathrm{~S}$ emission and occupational exposure.

\section{References}

[1] Al-Hamad, KH. KH. and Khan, A. R., Total emissions from flaring in Kuwait oilfields. Am. J. Environ. Sci., 4 (1): pp. 31-38, 2008. 
[2] Villasenor, R. M., Magdaleno, A., Quintanar, J.C., Gallardon, M.T., Lopez, R., Jurado, A., Miranda, M., Aguilar, L. A., Melgarejo, E., Vallejo., P. C. J. and Brachet, W.R., An air quality emission inventory of offshore operations. for the exploration and production of petroleum by the Mexican oil industry. Atmospheric Environment, 37: pp. 3713-3729, 2003.

[3] Dahl, C. and Kuralbaya, K., Energy and the Environment in Kazakhstan. Energy Policy, 29: pp. 421-440, 2001.

[4] Procedure for Preparing an Emission Summary and Dispersion Modeling Report, Version 3.0 Guidance for Demonstrating Compliance with Ontario Regulation 419/05; Air Pollution - Local Air Quality, made under the Environmental Protection Act. http://www.ene.gov.on.ca/en/air /ministry /index.php

[5] Turner, D.B., Workbook of Atmospheric Dispersion Estimates: An Introduction to Dispersion Modeling ( $2^{\text {nd }}$ ed.), CRC Press, 1994. ISBN 156670-023-X.www.crcpress.com

[6] Berkowicz, R., Palgrem, F., Hertel, O. and Vignati, E., Using measurements of air pollution in streets for evaluation of urban air quality-meteorological analysis and model calculations. Sci. Total Environ, 189(190): pp. 259-265, 1996.

[7] United States Environmental Protection Agency, EPA-454/B-95-003a, 1995, User's Guide for the industrial Source Complex (ISC3) Dispersion Models - Volume 1. Response Web Site, Washington DC, www.epa.gov/swerosps/bf 